\title{
Career Satisfaction Among Medical School Professors: a case study in Brazil
}

\author{
Satisfação Profissional de Docentes de Medicina: \\ um estudo de caso
}

Nilce Maria da Silva Campos Costa ${ }^{\mathrm{I}}$

\author{
KEY WORDS \\ - Teaching; qualitative research \\ - Medical education \\ - Professional satisfaction
}

Recebido em: 12/08/2008 Reencaminhado em: 04/11/2008 Aprovado em: 02/02/2009

PALAVRAS-CHAVE

Ensino; pesquisa qualitativa

- Satisfação profissional

\begin{abstract}
A B S T R A C T
Objective: To investigate the career satisfaction of medical school professors in relation to initial motivation, satisfaction factors, and the desire to remain in the profession. Methodology: A qualitative methodology was used, based on questionnaires and semi-structured interviews with faculty members at a federal institution of higher education in Brazil. Results: For $42.86 \%$ of the sample, teaching began while they were medical students; $80 \%$ had chosen teaching either as a vocation or due to influence from families or professors; $20 \%$ chose teaching as a professional opportunity. The majority, $57.14 \%$, stated they were happy with teaching, and $51.42 \%$ did not plan to leave the career. Factors involved in satisfaction with teaching were: the possibility of remaining up-to-date in the medical profession, the feeling of doing their duty, their contribution to training future doctors, and contact with young people and the university setting. Factors leading to dissatisfaction were pedagogical $(33.33 \%)$, economic (30.95\%), institutional (14.28\%), and relational (14.28\%). Conclusions: Subjects expressed a positive attitude towards teaching, and because of their great personal satisfaction with the career, they did not plan to leave it. These findings should shed light on factors that interfere with career satisfaction and help increase those that promote satisfaction, thus improving the productivity and well-being of medical professors.
\end{abstract}

\section{RES U M O}

Objetivo: Investigar a satisfação com a carreira docente de professores de medicina em relação à: motivação inicial, fatores de satisfação e desejo de permanência da profissão. Metodologia: Utilizou-se metodologia qualitativa; foram aplicados questionários e entrevista semi-estruturada aos professores de uma instituição federal de ensino superior. Resultados: $42,86 \%$ iniciou-se na docência como estudantes de medicina; $80 \%$ escolheram a docência por vocação, influência familiar e influência de professores e $20 \%$ por oportunidade; $57,14 \%$ consideram-se satisfeitos com a docência e $51,42 \%$ não pretendem se aposentar. Foram considerados como fatores de satisfação: possibilidade de atualização profissional, sensação de dever cumprido, contribuição com formação médica, contacto com jovens e com ambiente universitário. Os fatores de insatisfação citados foram os pedagógicos (33,33\%), econômicos (30,95\%), institucionais $(14,28 \%)$ e relacionais $(14,28 \%)$. Conclusões: Os pesquisados manifestaram atitude positiva frente à carreira docente e não possuem desejo de abandonar a carreira, pela grande satisfação pessoal. Esses achados podem contribuir com a reflexão sobre fatores que interferem na (in)satisfação da carreira docente e contribuir para que fatores de satisfação sejam aumentados, melhorando a produtividade e o bem estar de professores de medicina.

\footnotetext{
I Universidade Federal de Goiás, Goiânia, Goiás, Brasil.
} 


\section{INTRODUCTION}

Studies on the teaching career scarcely existed prior to the 1960s. They have only developed significantly since 1970, allowing a better understanding of teachers' professional lives ${ }^{1}$.

It would be helpful if teachers could go through definite phases in their careers. Since teachers construct their professional activity, they should be able to analyze and plan the sequence of career steps and even determine the nature and sequence of such steps ${ }^{1}$.

According to Garcia ${ }^{2}$, these career phases include: "pre-training", consisting of prior teaching experiences that can affect the teacher unconsciously; initial training or formal preparation in a specific institution; the initial teaching career or the early years of professional activity; and permanent training, with activities planned by both the institution and the teachers themselves to allow for professional development.

Huberman $^{1}$ analyzes phases in both the professional and personal dimensions: career entry, stabilization, diversification, questioning, serenity and affective distancing, conservatism and regrets, and finally disinvestment in the profession.

However, the phases that teachers undergo do not have a fixed duration and may be affected by the type of involvement in and personal commitment to teaching, positive and negative life experiences, enthusiasm, interest, personal problems accompanying the profession, sources of work satisfaction and dissatisfaction, institutional support, and even relations with co-workers ${ }^{1}$.

Career building is not a linear process of simply moving from one phase to another. In teaching, two different dimensions coexist: the professional dimension, consisting of the phases in which an institutional career is structured, with incentives in the form of recognition, promotions, remuneration, etc., and the personal dimension, consisting of the personal experiences the teacher goes through "until reaching his professional prime" 3 .

Studies of medical professors show that teaching is considered secondary to the medical profession per se, i.e., that teaching is not considered a profession in its own right ${ }^{4,5}$. Professors in the latter years of medical school (that teach clinical rounds, clinical training, etc.) are generally qualified in their specific areas, and hiring criteria in medical schools usually focus on technical performance ${ }^{6-9}$, with the personal dimension and teacher training relegated to a secondary role. The fact that the ability to affect students is based on who the professors are as people, how they present themselves, and how they relate to students is disregarded. Nevertheless, the way the professor "is, feels, or lives, and his expectations as he goes about his work" may affect teaching quality ${ }^{3}$. In other words, how teachers teach depends directly on who they are as people when they teach ${ }^{10}$.
Personal fulfillment and career satisfaction are essential aspects of the personal dimension of university teachers ${ }^{3}$. Changes in attitude and emotional state occur over time, and these can affect work performance, since factors leading to satisfaction and dissatisfaction reflect the investment made in the career. Satisfied professionals are less likely to change their attitude at work $^{11,12}$.

Job satisfaction studies have been carried out with the goal of improving worker retention in the health sector. They demonstrate the relationship between job satisfaction and time on the job $^{13,14}$, despite the complexity of assessing job satisfaction and the factors that affect it ${ }^{15}$.

The aim of this study was to investigate the career satisfaction among medical faculty at a federal institution of higher education in Brazil, in relation to initial motivation, factors leading to satisfaction or dissatisfaction, positive and negative experiences in their early careers, and their desire to remain in the profession.

\section{METHODOLOGY}

A qualitative study was conducted with professors of medicine working at the undergraduate level (a criterion for inclusion in the study). A questionnaire and semi-structured interview were used to collect data. The questionnaire was organized to identify length of time at teaching, academic qualifications, classes taught, working conditions in the medical school (physical layout, equipment, administrative structure, and salary), teacher training, positive and negative experiences in their early careers, and workplace within the hospital. This first phase of the research was used to gather data, "the indispensable foundation for the later detection of explanatory trails"16 (p. 22).

The interview, the script of which was not known in advance by the subjects, sought answers to questions suggested by the teachers' own narratives. For Turato ${ }^{17}$, when a qualitative research approach is chosen, "only an interview with open questions, that is, with only a proposed list of topics, and with no pre-established responses, is compatible with the definition of qualitative research" (p. 315-16). It was thus possible to speak freely about personal aspects of teaching such as factors leading to satisfaction or dissatisfaction, discouragement or crises, factors that lead teachers to stay in the profession, involvement with the institution, and end-of-career feelings.

In the first stage of the research, the questionnaire was given to 53 teachers who volunteered to participate in the study $(50 \%$ of the total contacted). Of the 53 teachers answering the questionnaire, 35 (66\%) participated in the second stage of the study, the semi-structured interview. 
The interview data were audio-recorded and later transcribed verbatim. The material was then submitted to thematic content analysis ${ }^{18}$.

The understanding and interpretation of the data obtained through the interviews complemented the data collected through the questionnaires ${ }^{19}$. Teacher satisfaction or dissatisfaction was identified in this study both directly, through a specific question in the interview, and indirectly, through an analysis of the reported pros and cons of teaching.

The nature of the data determined their treatment. EPIINFO version 6 was initially used to analyze the closed questions on the questionnaire. In this way, the quantitative data needed for mapping the object of the study were obtained. The questionnaire also included open questions that were analyzed qualitatively. This information was later interrelated with the data obtained in the interview and in class observations.

Content analysis, "perhaps the most usual approach to data analysis in research using qualitative methods"17 (p. 442), was used to analyze the interview material. Content analysis needs to transcend the mere description of the material obtained in order to include so-called inferences, since the reason for using this analytical technique in the first place is to be able to "discuss /infer on the basis of the data" ${ }^{17}$ (p. 443).

The phases involved in analysis of the interviews will now be described.

\section{Pre-analysis}

Pre-analysis is the initial phase of content analysis, in which the analyst makes "contact with the documents to be analyzed and becomes familiar with the text, letting himself or herself be invaded by impressions and orientations" ${ }^{18}$ (p. 96).

The first approach to the material consisted of so-called "fluctuating readings"17. Thus, immediately after the final data collection, reading of the material obtained in the interviews and observations was resumed. Little by little, a new, clearer perspective, still not crystal-clear, but with new possibilities for understanding the data, began to appear through the accumulation of evidence (or the lack thereof). It was then possible to move on to the categorization phase, which for Bardin ${ }^{18}$ (p.117) is the classification of the "elements constituting a set, by differentiation and later by regrouping according to type."

\section{Categorization}

For categorization, the criteria of repetition and relevance in the discourse of interviewees were used ${ }^{17}$. This provided an initial list of the categories to be analyzed and interpreted later. In fact, the topics of interest in the research, previously defined as "thematic units", fall into categories. According to Minayo ${ }^{19}$, analytical categories "may be considered markers for general knowledge of the object, and involve several levels of abstraction, generalization, and approximation."

In addition to categorization, Turato ${ }^{17}$ (p. 445) defends the strategy of sub-categorization, given the large amounts of material generally accumulated in qualitative approaches. Sub-categorization is defined as a procedure that "highlights, within a large topic (the category), other topics that deserve discussion but which retain a certain thematic dependence on a broad categorized topic."

The initial categories were thus subdivided into subcategories. The interview material was submitted to a "filtering" process, during which essential elements for the study's objectives were separated out.

\section{Coding}

Categories and subcategories were then coded numerically. Coding is a way of organizing the categories of interest.

\section{Categories and Subcategories}

\section{Interest in teaching as a career}

vocation/ pleasure
family
former teachers
opportunity

\section{Previous teaching experience}

\section{Teacher training}

Types of training

Positive and negative factors in teacher training

\section{Influences on teaching practice}

Inspiration from former teachers

In-service training

\section{What's easy about teaching}

Pleasure

Practical classes

Relationship with students

Familiarity with the institution 


\section{Teaching difficulties}

Teacher (non-) training

Specific teaching-related topics

Large classes

Initial insecurity

Lack of university infrastructure

\section{Changes in pedagogical practice}

Working conditions for teachers

Teaching methodology

\section{Satisfaction/dissatisfaction with teaching}

\section{End-of-career feelings}

happiness/satisfaction/pride

nostalgia and insecurity

The research project was submitted to and approved by the Animal and Human Research Ethics Committee at the university hospital where the study was performed. Data collection began only after the teachers had signed an informed consent form.

As a qualitative study, with a non-randomized and unrepresentative sample, the results cannot be generalized, and this constitutes a potential limitation of the study.

\section{RESULTS AND DISCUSSION}

\section{Initial Motivation}

A total of $42.86 \%$ of the sample of professors began their teaching careers at high schools or university pre-admissions "cram schools" while they were still undergraduate medical students. These were reported to be practically the only employment opportunities available to university students:

I taught high school for three years while I was a medical student. (Teacher 8)

I started teaching when I entered medical school, out of financial necessity, because I had no other way of supporting myself. (Teacher 12)

Starting in college, as a way to earn money, I taught in cram schools or gave private classes. (Teacher 21)

When I was a medical student I taught high school [...]. It was the only job market we had access to. (Teacher 22)
These early teaching experiences constitute the "initiation phase", consisting of the early years of teaching experience, during which the teachers learned by doing ${ }^{2}$.

The professors became interested in teaching for both active and passive reasons. Active reasons were characterized by internal motivation and personal desire, while passive reasons involved intervening circumstances or professional opportunities ${ }^{20}$.

The majority $(80 \%)$ of the 35 professors stated that they had chosen the teaching career for active reasons, particularly vocation or calling $(60 \%)$ and the influence of family and their own teachers $(20 \%)$. These findings are broadly similar to those obtained by $\mathrm{Hu}-$ berman $^{1}$ and Loureiro ${ }^{20}$ in studies of secondary school teachers, where active reasons for joining the teaching career predominated.

Among vocational factors, enjoyment of teaching, of giving classes, and the desire to be a teacher were cited. Some respondents had manifested this desire/vocation since childhood:

I remember the first time I taught. I remember it well; I was still in kindergarten. I was chosen to be a Portuguese monitor, to teach my classmates. I liked being a monitor (Teacher 2)

I recall that when I was still a child, I was already teaching my brother and younger cousins. My mother had me teach because I was further along. I was older. (Teacher 10)

I've always enjoyed teaching, ever since I was a child. I played at teaching. I had my own blackboard. (Teacher 27)

Others had come to this realization later in life:

I always really enjoyed explaining, studying, analyzing things deeply, and I had the opportunity to teach high school for a year, and later the opportunity, at college, of being a monitor. (Teacher 16)

During residency we're responsible for advising students, and I think this is a great advantage, because we study more, more is demanded of us. That was my first contact with teaching. (Teacher 18)

I enjoyed teaching ever since the beginning of medical school. And as a graduate student I was increasingly stimulated in this direction. (Teacher 24) 
I've been teaching since 1977, since I was a monitor in medical school. I think that experience convinced me that I could have a future in teaching. I enjoyed it a lot. (Teacher 26)

I entered medical school and really enjoyed learning, and thought the professor's role was very important. I admired the professors a lot. By the time I left medical school, I knew I wanted to be a professor. (Teacher 10)

Interestingly, women particularly refer to the importance of family in their career choice. This corroborates the findings by Tardif ${ }^{21}$, who confirmed that it was mainly female teachers whose families had led them to the teaching career, because either they came from a family of teachers or the teaching profession was highly regarded in their milieu.

Most of the women in my family are teachers. So I already had this background from my own family, this knowledge of what teaching involved. (Teacher 1 ).

My family was a family of educators. My mother, my father, and my brother were all teachers. So this was a big influence. I was born into this environment. (Teacher 3)

My mother was a teacher and loved it. (Teacher 7)

The influence of former teachers:

It was my contact with a professor, a very pleasant person, and his personality really influenced me. He was a great teacher. In addition to being a great doctor, he was a great teacher. (Teacher 15)

Passive reasons (20\%) involved offers and opportunities that came up at a particular time in life:

When I graduated, teaching wasn't exactly my plan. I wanted to be a practitioner, to see patients as a doctor. But opportunities in life are like that. You think about one thing and something else comes up later. (Teacher 8)

The medical school administration invited me at the time, because they needed a professor of
[...] and I accepted. I had never considered being a teacher. (Teacher 11)

\section{SATISFACTION AND DISSATISFACTION FACTORS}

Professors' professional satisfaction is regarded by specialists "as the professors' positive feeling and way of being in regard to their profession, originating in contextual factors and/or displayed through dedication, defense, and even happiness in regard to it" 22(p. 84). The opposing manifestations indicate dissatisfaction. In other words, satisfaction refers to a positive general and emotional state.

One of the theories explaining professors' degree of satisfaction is that of $\mathrm{Miskel}^{22}$, which includes three satisfaction-generating factors: motivating, health-related, and environmental factors. According to Herzberg ${ }^{13}$, personal satisfaction derives both from internal factors, such as self-realization and professional recognition, and external factors, such as salary and the interpersonal relationships established in the work environment.

Factors determining satisfaction/dissatisfaction with the teaching career can be economic, institutional, pedagogical, relational, and social ${ }^{22}$. In the current study, teaching was seen as pleasurable by a clear majority of professors $(57.14 \%)$ :

It is what I like to do most. I earn less, but it's what I enjoy the most. (Teacher 13)

Of all the things I do in life, teaching is the most enjoyable thing, the most pleasurable. (Teacher 1)

The satisfaction is enormous. (Teacher 8)

I'm satisfied, I feel happy. (Teacher 24)

It's great. I love it, definitely. (Teacher 27)

I'm in love with it. (Teacher 35)

I enjoy it so much I can't tell you. (Teacher 6)

I could have retired a long time ago. When I'm forced to retire, and that isn't too far away, I intend to continue as a volunteer in this school, because I like it a lot. (Teacher 9)

Outstanding factors leading to satisfaction among medical school professors include the possibility of keeping up-to-date professionally, a feeling of doing one's duty, gratification in helping train doctors, contact with young people, and the feeling of belonging to a family environment: 
It keeps me constantly up-to-date. It's an enormous stimulus to stay up-to-date. I don't know if I were just at my clinic, at my office - if I would be thinking, discussing, and studying at the same level I am here. (Teacher 15)

It's a way to stay permanently in contact, permanently up-to-date. (Teacher 20)

To participate, to make a contribution. There are people in the job market who are thanking us all the time. (Teacher 8)

I think I've managed to pass something on to others who are going to take it with them. I find this highly rewarding. (Teacher 5)

Because it is gratifying to follow a person's progress, to teach something and witness the person's progress. (Teacher 20)

Those who teach are often really touched. You feel that the students are connected, that they're feeling emotion. When I have a class that's connected, it motivates me even more. I even get a thrill when I'm giving a class. This happens with me, I don't know if they notice, but it does. (Teacher 25)

The best thing is that I don't think I've aged. Being in the midst of young people, I stay young. (Teacher 8)

My biggest dream is to be here. To go to the hospital, then to go home with a sense of having spent the day where people were trained. (Teacher 6)

Professors also referred to factors leading to dissatisfaction: pedagogical $(33.33 \%)$, economic $(30.95 \%)$, relational $(14.28 \%)$, institutional (14.28\%), and others (7.14\%):

Pedagogical factors, in the form of unsatisfactory working conditions, were mentioned as the main obstacle to teaching:

A lot of basic items, elementary for a university, for a medical school, simple things, just aren't provided. Teaching material, hospital material. There is a great lack of money, there's no money, a Franciscan poverty. No chalk, sometimes no bandages, not even the bare minimum. (Teacher 10)

This place is really poor. Sometimes it's "Today there's no rehydration fluid, today there's no penicillin." The environment is inadequate. We're out of this, out of that. (Teacher 6)

Professors cited adverse infrastructure conditions, whether they made a positive or negative overall assessment of teaching. The overall attitude thus depended on whether the positive or negative aspects prevailed, which related to the concept of a polarity between satisfaction and dissatisfaction ${ }^{22}$.

As far as economics is concerned, dissatisfaction was expressed with professors' salaries in the Brazilian public sector, as the result of social devaluation of teaching. This can have negative consequences for teaching, since the social imbalance between the roles of doctor and professor can be a source of problems for the institution, given that professional investment is generally proportional to pay:

The salary is very low [...]. I think professors should be paid better. Professors deserve more respect. (Teacher 5)

Depreciation of salaries is especially bad. Your work is not recognized [...] all the work you do is disregarded. None of your dedication has any value. I think this is terrible. It kills any idealism. It kills any kind of work. (Teacher 34)

As mentioned, devaluation of teaching has negative consequences, since the imbalance between the roles of doctor and professor can cause problems for the institution, given that professional investment tends to be proportional to remuneration. In the professors' responses, low salaries are a justification for less dedication to the teaching career:

I'd like to be a full-time teacher. I'd like to earn enough to work full-time here, but I don't. This is a reason for dissatisfaction. (Teacher 30)

You can't live on this kind of salary. So you have to have a thousand other jobs to justify this one, and you wind up not devoting enough time to it. (Teacher 35)

The pay is low. It's not enough to survive on. So it's like moonlighting. (Teacher 11)

If we earned enough to support ourselves, we'd have more time to devote to teaching. (Teacher 12)

Among the relational factors, lack of integration with colleagues and their resistance to change stand out. Among institutio- 
nal factors, the powerlessness of administrative positions was the most widely cited:

In all of the administrative positions that I've occupied, leadership positions, I felt unable to do things because the structure just wasn't there. You can have all the goodwill in the world, but you always run up against brick walls that are difficult to climb over. (Teacher 2)

\section{DESIRE TO REMAIN IN OR LEAVE THE TEACHING PROFESSION}

When asked whether they intended to continue their teaching career, $51.42 \%$ responded that they were not planning to leave teaching:

I'll be a teacher till I die. (Teacher 12)

I intend to stay at the university until I stop working, until I'm no longer able to work. (Teacher 30)

If they were to begin all over again, the professors would choose teaching for basically the same reasons that motivated their initial choice. Since teaching provides a feeling of professional achievement, it helps consolidate the initial choice, as seen in the statement by a teacher whose teaching career spans 25 years:

I think if I had it to do it all over again, I would, even knowing that economically speaking, it carries no prestige whatever. (Teacher 3)

Despite the enjoyment teaching provides, the job was found to be a source of personal wear-and-tear and at times frustration, with several professors undergoing "crises" ${ }^{3}$. While some professors reported experiencing crises at some point in their careers, others found no connection between a personal questioning about remaining in the profession and "professional disinvestment" ${ }^{20}$. On the contrary, some professors undergoing a professional crisis continued to invest in further education:

When I was really discouraged, and thought it really wasn't worth it, I decided: "I'm going to get a Master's." I was on leave for two years to do my Master's, and when I came back I felt better. (Teacher 10)

I had a number of crises. I had one when I did my doctorate. I was ready to leave the university and was heartbroken and thought it was time. I wasn't going to be able to change very much of what was there, and this frustrated me more than it pleased me. I took a leave of absence for my doctorate and it was wonderful. I came back with much more enthusiasm. (Teacher 34)

\section{PLUSES AND MINUSES OF THE TEACHING CAREER}

In general, the professors in this study had not experienced major difficulties at the beginning of their careers. The difficulties were of two kinds: pedagogical and those caused by lack of teacher training. The former can be considered, at least in part, as a consequence of the latter.

The pros and cons reported by professors translate what they felt and experienced in their day-to-day teaching experience. One of the pros of teaching is pleasure in the act of teaching:

It's a plus because I like it. I like to study, and I like to give classes. (Teacher 27)

Ilike to teach, I've always enjoyed it. (Teacher 28)

The positive relationship with students, predominant among professors in this study, was also a defining characteristic for the pleasure in teaching:

I enjoy dealing with students, students who ask questions, who learn. From time to time I run into a student who remembers a class I gave. This stimulates me. (Teacher 10)

The students themselves try. They're dedicated. There are subgroups that are very interested, and this makes things much easier. The stimulus, the dialogue, and things flow along nicely. (Teacher 16)

Other positive factors reported by professors were technical mastery and familiarity with the institution:

The fact that I had a lot of content to give was a very big plus factor. [...] I had a lot of information, and in our area this carries a lot of credibility. (Teacher 13)

When I started I already had good experience, good knowledge. I was sure of myself technically. (Teacher 23)

Working where I got my own training made things easier for me. (Teacher 3) 
Starting a career without training may actually be a reason for the lack of initial difficulties. Lack of awareness of the complexity of teaching skills, as well as confidence in the technical side, may have made up for the lack of teacher training. Scientific mastery can be interpreted as a factor making the beginning of a career less difficult since it compensates for other things that are missing in this period ${ }^{20}$.

Mastery of teaching does not happen by chance. It cannot be expected that a young person starting a teaching career, even with a doctorate, is ready to deal with teaching. Professional development means becoming more rational, more specialized, and more effective, a process that involves knowledge, feelings, and experience in the area ${ }^{3}$. The main difficulties mentioned were evaluating students' learning (25.7\%), dealing with large classes (14.28\%), preparing classes (14.28\%), having little contact with students $(11.49 \%)$, and not having guidelines for teaching $(5.71 \%)$.

Pedagogically speaking, evaluating students proved to be one of the main difficulties:

Evaluation was always very difficult. I always thought that I made a lot of mistakes in evaluation. (Teacher 30)

Evaluating the student, what I was teaching, what the students were getting, learning. I had a lot of trouble with that. (Teacher 4)

The professors also complained about lack of contact with students, resulting from the course curriculum structure, with students divided up into various rotating sub-classes, thus minimizing teacher/student contact:

The student doesn't develop a feeling of confidence in you. I wouldn't say that he develops familiarity, or knowledge beyond the student-teacher connection, which you sometimes develop over certain courses. It's something that we used to have, where a high school student spent an entire year with the same teacher. (Teacher 2)

The course goes by too quickly. Students [...] have one month for each subject. So sometimes you don't remember everybody's name, and since there are several professors, and they're all doing something, the students move around a lot and you end up not remembering everybody. (Teacher 21)
I only teach certain subjects and I really don't like this. I don't think it's the best way. Several groups, I think it's frustrating for the teacher. (Teacher 26)

Dealing with large classes also causes discomfort:

It's the size of the class, with a hundred and some students, everybody together and you just aren't able. You realize that it's hard for people to pay attention to what you're saying. (Teacher 7)

Some professors refer to the lack of teaching guidelines:

The teachers do more or less what they want. This is a big problem. There's no pedagogical program. (Teacher 9)

The professors reported difficulty in teaching without having received specific teacher training:

I suffered a lot because of my lack of experience, lack of preparation as a teacher. I had experience as a doctor. Teaching, testing, the technical part of being a teacher, I lacked. (Teacher 11)

Not having teacher training. I had trouble with lesson plans. I didn't know what a course plan was. I didn't know how to fill out a daily course record, these things that are basic to teaching. (Teacher 1)

My biggest problem was the lack of teacher training. (Teacher 8)

That's just it. You start thinking, "If I know the content, I know how to teach the content." (Teacher 13)

The problem is that we don't get teacher training. Our training is medical. We wind up being doctors who teach. So that was the biggest difficulty I experienced, methodologically speaking, didactically, in giving classes. (Teacher 27)

The professors also recognized that, over time, the phases of their teaching careers diversified, as shown in the increase in their professional involvement with the teaching institution. With years of practice, the teachers became more motivated to search for new career challenges, translating into a desire to assume management positions that would help maintain enthusiasm for the profession. 
Teachers with more than 20 years of experience made important observations:

I reached the point where I thought I could give a little more, that is, get more involved and work more with the institution, with what I had in my head, what I had learned and what I felt I could give back. (Teacher 30)

If you're concerned about teaching, you continue to acquire knowledge about it [...] you want to be in a better and better position in order to affect teaching even more positively. (Teacher 35)

As far as feelings are concerned, the statements point to positive and negative experiences, with a predominance of the former. The negative experiences were less intense, in the form of difficulties experienced while teaching, ranging from the initial insecurity deriving from lack of experience to the constant dissatisfaction caused by inadequate working conditions and downgrading of teaching.

According to the findings, external factors heavily affect professional development. Abstracting the professor's work from the material conditions under which it is carried out would be to consider it a homogeneous job resulting from a general norm that implicitly declares this uniformity. The practice of teaching, however, is not a homogeneous situation and is carried out in specific conditions involving the relationship between the professor and his institution, conditions that characterize the institution and the practice of teaching.

Satisfaction of individual needs is a determining factor in professors' perceptions and attitudes, including their own professional activities. In other words, the professors work with the aim of satisfying both their personal and professional needs ${ }^{3}$.

\section{CONCLUSION}

The findings related to the categories "initial motivation", "attitude toward the profession", and "desire to remain in or leave the profession" proved to be quite consistent.

The professors revealed that they obtain satisfaction from their teaching. Choosing the profession of their own free will appears to be a determinant of professional satisfaction, contributing positively to career development.

Most of the interviewees began teaching for active reasons, but even those motivated by passive reasons became involved in the profession, showing a positive attitude and not even considering the possibility of leaving.
A positive attitude toward teaching is justified by the presence of personal satisfaction factors. In other words, a positive attitude toward teaching shows that the professors give priority to inner reasons for satisfaction and are less susceptible to unfavorable external factors.

The quality of teaching is also determined by material and institutional conditions, and if changes are desired, it is indispensable to change these conditions. Thus, a reduction in the causes of teacher dissatisfaction towards working conditions, more budget, and better pay could help make the university more dynamic. With fewer causes of dissatisfaction, professors would be motivated to do better work.

But work satisfaction increases not only with changes in external, organizational factors, which merely lower dissatisfaction, but also in the subject-work relationship. This means that satisfaction can increase when the teachers' relationship to work is improved, when there is responsibility and decision-making autonomy, learning of new skills, an expectation of professional growth, and recognition and reinforcement of the professional vision of the work performed.

These are challenges for medical training in Brazil and are related to institutional, management, and financial aspects of the educational system. Career satisfaction factors differ from those that lead to dissatisfaction and, for this reason, it is not enough to eliminate factors leading to dissatisfaction in order for teachers to feel satisfied.

Further research on factors generating satisfaction in medical professors in particular, and in the health area in general, are necessary in order to broaden this field of knowledge.

\section{REFERENCES}

1. Huberman M. O ciclo de vida profissional dos professores. In: Nóvoa A. Vidas de professores e sua formação. Porto: Porto Editora; 1995 . p .31-61.

2. Garcia CM. Formação de professores: para uma mudança educativa. Porto: Porto Editora; 1995. p. 272.

3. Zabalza MA. O ensino universitário: seu cenário e protagonistas. São Paulo: Artmed; 2004. p. 239.

4. Batista NA, da Silva SHS. A função docente em medicina e a formação/educação permanente do professor. Rev Bras Educ Med. 1998; 22: 31-6.

5. Masetto MT. Docência na Universidade. Campinas: Papirus; 1998. p. 112p.

6. Bireau A. Os métodos pedagógicos no ensino superior. Porto: Porto Editora; 1995. p. 225. 
7. Batista NA, da Silva SHS. O professor de medicina: conhecimento, experiência e formação. São Paulo: Edições Loyola; 1998. p. 181

8. Lampert J. Tendências de mudança na formação médica no Brasil: tipologia das escolas. São Paulo: Hucitec ; ABEM; 2002. p. 283.

9. Mcleod PJ, Steinert Y, Meagher T, Mcleod A. The ABCs of pedagogy for clinical teachers. Med Educ. 2003; 37: p. 638-44.

10. Nóvoa A. Formação de professores e profissão docente. In: Nóvoa A. Os professores e sua formação. Lisboa: Publicações Dom Quixote; 1997. p.15-33.

11. Goodell TT, Coeling HVE. Outcomes of nurses' job satisfaction. J Nurs Adm. 1994; 24: p. 36-41.

12. Gaither CA. Career commitment: a mediator of the effects of job stress on pharmacist's work related attitude? J Am Pharm Assoc. 1999; 39: 353-361.

13. Moore K, Cruickshank M, Haas M. Job satisfaction in occupational therapy: a qualitative investigation in urban Australia. Aust Occup Ther J. 2006; 53: 18-26.

14. Murphy JG. Satisfaction with practices: emergency physician versus internists. Ann Emerg Med. 1987; 16: 277-283.

15. Gerrity MS, Pathman DE, Linzer M, Steiner BD, Winterbottom LM, Sharp MC, et al. Career satisfaction and clinician-educators the rewards and challenges of teaching. J Gen Intern Med. 1997;12: 90-97.

16. Estrela A. Teoria e prática de observação de classes: uma estratégia de formação de professores. $4^{\circ}$ ed. Porto: Porto Editora; 1994. 479p.
17. Turato ERT. Tratado da metodologia clínico-qualitativa. Petrópolis: Vozes; 2003. 685p.

18. Bardin L. Análise de conteúdo. Lisboa: Edições 70; 1977. $229 \mathrm{p}$.

19. Minayo MCS. O desafio do conhecimento: pesquisa qualitativa em saúde. São Paulo: Hucitec; Abrasco; 1992. 269p.

20. Loureiro MI. O desenvolvimento da carreira dos professores. In: Estrela, MT. Viver e construir a profissão docente. Porto: Porto Editora; 1997. p.117-149.

21. Tardif M. Saberes docentes e formação profissional. Petrópolis: Vozes; 2002.323p.

22. Alves FCA. Satisfação dos professores. In: Estrela MT. Viver e construir a profissão docente. Porto: Porto Editora; 1997. p. 81-116.

\section{CONFLICT OF INTERESTS}

The authors hereby declare that they have no conflicts of interest.

\section{CORRESPONDING ADDRESS}

Nilce Maria da Silva Campos Costa

Rua 15, nº 220, ap.1000

Setor Oeste - Goiânia

CEP.: 74140-035 GO

E-mail: nilce@fanut.ufg.br 